\title{
Recent Phases of Competition in International Trade
}

\author{
By William B. Colver ${ }^{1}$ \\ Chairman, Federal Trade Commission
}

A LTERED competitive conditions in international trade reA sulting from the world war have completely disarranged the world's commercial chessboard. A regrouping is taking place whereby the relative positions and spheres of influence of the leading commercial countries are being vitally affected.

Prior to the war Great Britain, Germany, the United States and France, in the order named, divided the lion's share of the world's foreign trade. Now the way seems open for the United States to take first place. From a debtor it has become the leading creditor nation of the world.

Japan's foreign trade exhibits a remarkable growth. In 1913 it had a balance of trade of imports over exports of approximately $\$ 48,485,715$. In 1917 the export trade of Japan showed a balance of $\$ 283,606,295$ over imports.

Of the neutral countries of Europe, Sweden, Denmark and Spain show a great proportionate growth in their foreign trade during the war, as do also Argentine, Brazil and Chile. On the other hand Great Britain and France have suffered heavy losses in the money value of their foreign trade. So, too, Russia, the Netherlands and Norway.

This universal dislocation of commerce and trade, involving loss of trade on the one hand and acquisition of new markets on the other, has greatly stimulated activity in foreign trade. Efforts to regain what has been lost or is being endangered by new competitors, and to hold and expand what has been newly acquired, surpass all precedents in scope, in keenness of rivalry and in systematic methods of endeavor. The attention of business men has been thoroughly aroused as to the future possibilities of foreign markets, not as dumping grounds for temporary over-production, but

${ }^{1}$ Acknowledgment is made to the patient and helpful assistance of Dr. William Notz of the Federal Trade Commission staff, in the preparation of this paper. 
as permanent fields for enterprise. Individual and collective efforts on the part of private concerns to establish and foster trade relations with foreign markets are being backed up by government aid and coöperation. A world-wide drive for foreign trade has begun.

\section{Great Britain}

The most comprehensive preparations for promoting foreign trade made during the war by any of the leading industrial countries of the world have been made by Great Britain. Her oversea trade machinery has undergone a complete over-hauling. Shortly after the outbreak of the war Sir Edward Grey voiced the view generally prevailing in British official circles as well as among business men and others interested in commerce and industry as follows:

If we want to capture trade in neutral markets we must see to it that we have high production instead of low. The other want of ours is industrial organization. Without this we cannot successfully compete with American and German industries, which, owing to their own superior method, work en masse. We are far too individualistic as a rule. We have to combine to hold our own.

This plea for concerted effort for solidarity of trade interests at home and for coöperation in meeting foreign competition found a responsive audience. Henceforth economic unification of the different industries of the United Kingdom, and on a larger scale economic nationalism of the business interests of the whole Empire became the watchword, and gave a new direction to the commercial policy of the nation.

\section{The Committee on Commerical and Industrial Policy after the War}

In 1916 the Prime Minister appointed a Committee on Commercial and Industrial Policy after the War which was "to consider the commercial and industrial policy to be adopted after the war." Among its terms of reference, this committee was to consider "what steps should be taken to recover home and foreign trade lost during the war, and to secure new markets." In its final report presented to Parliament in 1918 the committee points out, among other things:

That notwithstanding the strength of the United Kingdom's economic position, there is a widespread feeling that a reconsideration of our industrial and trade 
organization has become necessary in consequence of the increasing intensity of foreign competition, based largely upon a system of combination in respect of production and distribution which has hitherto made comparatively little progress in the United Kingdom. While there is a danger that consolidation and combination not only may tend to diminish individual initiative and enterprise to which the progress of British manufacture and industry has been largely due, but also may be carried to a point at which it becomes inimical to the general interests of the country, we agree generally with the opinion that in some important directions the individualistic methods hitherto mainly adopted should be supplemented or entirely replaced by coöperation and coördination in respect of (1) the securing of supplies of materials, (2) production (in which we include standardization and scientific and industrial research), and (3) marketing. . . . We recognize that the formation of organizations for marketing in respect of overseas trade will stimulate the creation of combinations for the control of domestic sales. We believe, however, that such development is not only desirable in some cases, but practically inevitable under modern conditions, and that the attitude of public opinion, of local authorities and the state, which has hitherto been antagonistic, must be modified. We consider, moreover, that, so far from being adverse to the interests of labor, combinations of employers are on the whole beneficial to the workers in the trade affected in respect of rates of wages, steadiness of employment and other matters.

'The policy advocated by the committee has been actively promoted by the British Board of Trade during the past two years.

$$
\text { Fostering “Key" Industries }
$$

Two further points emphasized by the Committee on Commercial and Industrial Policy after the War relate to certain essential industries. These so-called "key" or "pivotal" industries comprise certain special commodities which are considered essential to national safety, as being absolutely indispensable to important British industries, and which were supplied before the war entirely or mainly from present enemy sources under present enemy control. In addition to synthetic dyes and spelter, they include tungsten, magnetos, optical and chemical glass, hosiery needles, thorium nitrate, limit and screw gauges, and certain drugs.

Regarding these "key" industries the committee recommended "that they should be now maintained in Great Britain at all hazards and at any expense," and that "failing efficient and adequate output, the government should itself undertake the manufacture of such articles as may be essential for national safety." The committee recommended the establishment of a permanent board to be known as "the Special Industries Board" charged 
with the duty of watching the course of industrial development and of framing from time to time detailed schemes for the promotion of "key" industries. This board is to be represented in Parliament by the head of the respective department which is entrusted with the care of the commercial and manufacturing interests of the country.

Already action has been taken by the British government to foster certain "key" industries, particularly that of artificial dyestuffs. Under a special law the British government has granted large subsidies to British dyes and other dyestuff manufacturing plants. To strengthen further the industry, a scheme for amalgamating the leading British concerns manufacturing coal tar dyes has had the active backing of the Board of Trade and is now being consummated. The new concern, which will include British Dyes, Ltd., and Levinstein, Ltd., will convert the British dyestuff industry into one large national industrial unit, subsidized by the government, and powerful enough to cope with any foreign competition. On February 24, 1919, the Board of Trade issued an order prohibiting the import of dyestuffs except by license. A Trade and Licensing Committee, composed of an equal number of representatives of the dye manufacturing and dye using industries, will administer the order.

\section{The British Board of Trade Reorganized}

The inspiration and center of the whole movement for British trade expansion is the British Board of Trade. From there ambitious plans for reconstructing the domestic and foreign trade machinery of Great Britain have emanated, and have been put into execution. The board itself has undergone a complete reconstruction during the war. As constituted under the new scheme of organization the Board of Trade consists of two main departments - The Department of Commerce and Industry, and the Department of Public Service Administration.

The Department of Commerce and Industry is mainly concerned with the development of trade, with vigilance, with suggestion, with information and with the duty of thinking out and assisting national commercial and industrial policy. It is subdivided into the following divisions: (a) Commercial Relations and Treaties, (b) Overseas Trade Development and Intelligence, 
(c) Industries and Manufactures, (d) Industrial Property, (e) Industrial Power and Transport, (f) Statistics.

The Department of Public Service Administration is primarily engaged in the exercise of statutory and other administrative functions of a permanent nature with regard to marine affairs, public utilities and harbors, railways, companies and bankruptcy.

\section{Trade Association}

Side by side with the various activities of the British Government in its drive for promoting foreign trade, some of the preparations made by British trade associations for developing export trade merit special attention. The Federation of British Industries at its last annual general meeting in October, 1918, had a membership of 951 in which number 164 trade associations were included. The federation represents 16,000 manufacturing companies with a total capital of $\$ 20,000,000,000$.

The president of the federation in his presidential address said, among other things, that "it would add enormously to the strength of the federation and to British industry generally, if their huge membership would definitely adopt the policy of buying each others' products in preference to foreign goods." A resolution was passed:

That commissioners or representatives of the federation be appointed in each of such overseas markets as may be determined, who are to act as a center for collecting and classifying information from all parts of the market area to which the commissioner is accredited; to institute a close inquiry into the national resources of the country; to keep lists of likely men to act as agents for members; to retain a legal adviser in the country for the use of members; to encourage propaganda for British trade; to have a library for trade literature and catalogues; to give information as to the financial position of local firms; give advice on local and trade customs; to form a link with the representatives of the British government with a view to securing the assistance of the government for British manufacturers where necessary; to arrange for coöperative placing of advertisements; to create new or get in touch with existing associations of each country composed of the principal firms engaged or interested in industry; to appoint a local board of prominent business men in sympathy with British aims to advise him generally.

The British Manufacturers' Corporation is another trade organization which has recently been formed "to ensure British trade prestige in overseas "markets." Its membership includes large and small manufacturers in all industries. It is to serve as an instrument for the getting of orders from overseas. 
Sir Charles Mandleberg of Manchester, one of the founders of the corporation, recently said that "the aim of the corporation is to equip British manufacturers in every possible way for the coming struggle, and instruct that no manufacturing firm with hopes of increasing its export trade should be left outside this organization in the national interest, or can afford to remain outside it in its own interest. . . . . " The scheme which the corporation proposes to put into operation hinges upon the "man on the spot," the directing spirit in the foreign market who is:

To guide manufacturers in catering to trade, protect their interests, and be first on the track for possible orders for them. He is to secure the best agent in the country concerned; will retain the services of technical experts, and will generally communicate every change or development in trade requirements to the members. The home arrangements include an information bureau in the chief manufacturing centers here, and also facilities for advances of money and the guaranteeing of foreign accounts.

\section{Bank Amalgamations}

A matter of material importance and of vital bearing upon London's preëminence as the financial center of the world consists in the recent amalgamation of British banks. As a result of this process of concentration of financial power, there are now only five big London banks apart from the Bank of England. One of the most important bank amalgamations, effected in 1918, was that of the London Joint Stock Bank with the London City and Midland Bank. The branches and agencies of the two banks in foreign countries cover the whole world. Sir Edward H. Holden, chairman and managing director of the new concern, in a speech at the annual general meeting of shareholders in London on January 29, 1919, discussed the bank's financing of imports and exports for the past year as follows:

The acceptances amount to $£ 13,146,000$ against $£ 8,827,000$ last year. These are our acceptances on behalf of Colonial and foreign bankers, and it is through this medium that our imports and exports are financed. We must expect these figures to grow still larger now that the war is over because trade restrictions in this country and in foreign countries are being removed. When goods are shipped to this country from foreign countries they are paid for by the negotiation of the acceptances of the English bankers, and when exports are made they also are paid by the negotiations of these acceptances in one way or another. Of course the payment of these acceptances is ultimately made in London, and this has been one of the means by which London has become the financial center 
of the world. We hope, of course, that London will remain the financial center after the war, but this will depend to a large extent upon the accommodation which London bankers are able to afford foreign bankers by way of acceptances.

Sir Edward Holden, on the same occasion, referred to a plan of sending a part of the bank's staff abroad to work in foreign banks to acquire the language of other countries as well as a better knowledge of foreign business.

\section{Germany}

The victorious outcome of the war for the Allies has deprived German plans for future trade expansion in the world's market of their one vital prerequisite,-victory for the Central Powers. Virtually all of Germany's ambitious plans for international commercial supremacy,-whether they embraced the welding of closer economic relations between Germany and Austria-Hungary, the promotion of her trade with the Near East, with Latin America and other parts of the world, or whether they related to the importation of raw materials, the expansion of her merchantmarine and of her oversea banks,--were predicated on a victorious conclusion of the war on the part of Germany. The signing of the first armistice spelled disaster for Germany's ambitions as a leader in international trade.

The elaborate plans for rehabilitating her foreign trade worked out by the new Reichswirtschaftsamt (Imperial Department of Economic Affairs) which was organized during the war; the preparations made by private associations for promoting foreign trade, like the "Deutscher Levante Verband (German Levant Association) and others, appear impotent and innocuous in the light of the helpless economic condition in which Germany finds herself today. The politicai and industrial upheaval which followed the signing of the first armistice terms but accentuates her plight.

For the time being, at least, Germany is eliminated as an important factor in international trade. Some of her basic industries which figured very prominently prior to the war in shaping Germany's foreign trade policy are paralyzed. Her largest cartels, which during the quarter of a century preceding the war constitu= ted the backbone of Germany's commercial and trades enterprises in foreign countries, are in a state of dissolution. The abrogation 
by Luxemburg of her Customs Treaty with Germany caused some of the largest steel and iron plants to withdraw from the German Steel Syndicate. Other difficulties for the Steel Syndicate arise from the Allied occupation of the Saar and Lorraine, where works of other members of this Syndicate are located. It is announced from Essen that the local Workmen and Soldiers' Council has resolved to occupy the premises of the Rhenish-Westphalian Coal Syndicate as a preliminary measure toward the nationalization of the coal mines. Some of the leading plants controlled by the dyestuff cartel are in occupied territory. Far reaching hopes were placed on the ability of the German coal tar dye industry to regain the dominant position which it held in the world markets in the past. However, in view of the rapid development of this industry in the United States and Great Britain during the past four years, a realization of these hopes appears preposterous.

What is true of Germany holds good also as far as the other members of the Central Powers are concerned. Whatever plans for future competition and trade expansion in foreign countries have been formulated and advocated by the respective governments, by trade associations or individuals have been disarranged by the overwhelming industrial and commercial collapse following defeat.

\section{France}

The foreign trade of France has suffered severe losses during the war. While numerous plans for reëstablishing and strengthening her future position among the leaders in international trade have been discussed and advocated with much zeal in the French press, in trade circles and in parliament, the number of constructive measures actually initiated is comparatively small. Nevertheless the farsighted propaganda. work of such eminent statesmen and leaders as Ministers Clèmentel and Loucheur, Senator Flandrin, M. Vallière, M. Boret, M. Herriot, the energetic mayor of Lyons and others has inspired a number of far-reaching reforms.

The excellent studies of commercial and trade conditions at home and abroad made by the Société d'Encouragement à l'Industrie Nationale merit attention. The stimulus given by the economic research work of this and kindred societies to the metallurgical, electrotechnical, chemical and other industries of France has induced many industrial enterprises to rejuvenate themselves and 
to introduce comprehensive reforms of their commercial methods. Several trade associations have been formed for promoting the French export trade. One of these, the National Association for Economic Expansion, was established on December 15, 1915 under the auspices of the Paris Chamber of Commerce.

Among other things the association aims at opening up new markets for French products in foreign countries. The sample fair at Lyons has proved highly successful, and has become an international centre for the exchange of commercial and industrial information. The first fair was held at Lyons in 1916. At that fair $\$ 10,000,000$ worth of goods were sold, and another $\$ 8,000,000$ of orders were turned away because French manufacturers could not promise delivery during the war. At the 1918 fair there were 3,200 exhibitors divided as to nationality as follows: American, 543; English, 107; Italian, 40; Russian, 1; Swiss, 114; Spanish, 33; Dutch, 22; all the rest were French firms. This year the total number of exhibitors has advanced to 4,700 .

The law of April 13, 1917, for the encouragement of the maritime trade, authorized advances to French shipowners in France up to a total maximum of $\mathbf{1 6 0}$ million francs. The loans, bearing interest at 6 per cent are to be used for constructing or purchasing cargo vessels. It is provided in the law that for a period of two years the cargo of such vessels must be destined to or proceed from French ports.

The plan to make the Rhone navigable has been widely advocated during the war. The purpose is to afford Switzerland an outlet to the sea through France, and thus to direct a part of the Swiss overseas trade by way of Marseilles.

On March 15, 1918, the Chamber of Deputies made the general question of commerce and industry after the war, part of its order of the day. On that occasion, amid general approval, $M$. Vallière presented a program for economic reconstruction which embraced among others, the following points:

1. Reduction of the price of French manufactures by modernization, standardization and improved technique.

2. Improvement of technical education.

3. The coöperation of shops and yards for studies and research of all kinds, for the purchase of raw materials, the discovery of markets, the shipments of finished products at common expense. 
4. Adaptation of French products to the taste of customers, as a means toward the conquest of foreign markets.

5. Development and cheapening of transportation.

6. Retention of French money for French enterprise, establishment of financial facilities, such as long credits, etc.

7. Reservation of mineral resources for the French, with limited concessions of mines, and state participation in the profits.

8. Assistance to production, with a view to reducing imports.

9. Assistance with a view to increasing exports of manufactures.

10. Increasing the number of state enterprises, and of those in which the state shares the profit.

11. The deepening of rivers and harbors, building of a merchant marine and of new marine basins.

Several of these proposals have already been initiated and the vigor with which they have been furthered during recent months bespeaks a promising future for the industrial and commercial life of France.

\section{Scandinavian Countries}

Indications that the business men of Norway, Sweden and Denmark are fully alive to the future competition in overseas trade are plentiful. In November last year a congress of Scandinavian business men was held at Christiania at which trade organization for the post-war period was discussed. In the course of this meeting it was pointed out that during the war the course of development has everywhere been in the direction of concentration, cartels and the formation of monopolies. In all the more important countries and markets in which Norway is interested, competition, it was stated, will be encountered from strong private combinations, and also, to some extent, from rings enforced or supported by the state, with the object of controlling the entire foreign trade. It was argued that, being confronted by great organizations in overseas markets, the work of placing surplus exports at the most advantageous prices and of buying articles of consumption at favorable prices, must be carried out by organization and unity. Exporters were urged to operate in a body, whilst importers were advised to resign themselves to collective operations even on the foreign markets, where the individual would very frequently be subordinate and compelled to accept unfavorable prices. Finally it was pointed out that the conditions of the future will demand a higher mercantile culture all around. 
Coöperation with the importers and exporters of neighboring countries-Sweden and Denmark-would also strengthen Norway's position as buyer and seller. This form of economic coöperation in the North seems certain to come to the front in the future, and gain the greatest significance when complemented by the interchange of goods between the three countries.

In Sweden the policy of coöperation for export trade has been put into actual practice on a large scale. Last year twenty Swedish industrial associations combined to form an export council, called the Svenska Exportindustriernas Centralrad. The most important members are the Iron Institute, the Swedish Cellulose Association, the Swedish Wood Pulp Association, the Swedish Timber Export Association, the General Export Association of Sweden, the Swedish Industrial Association, the Swedish Chemical Industries Office, the Swedish Machine Industries Association, the Swedish United Goods Association, and the Swedish Timber Industries Association.

Sweden's plans for developing her commercial future embrace among other things closer relations with the Baltic trade. With this object in mind plans are now being carried out for making Malmo a free port. It is believed that a large volume of transshipment trade will be drawn to that port, and that ultimately Malmo will become the leading trade centre on the Sound.

\section{JAPAN}

The expansion of Japan's trade and industries during the war has been phenomenal. Large orders for munitions from the Allies and requirements from the Far Eastern countries and the South Seas, where the imports from Germany and other belligerents had ceased to come, enlivened the export trade. The scarcity of freight space throughout the world and the abnormal rise of charterage of Japanese ships engaged in foreign trade stimulated shipbuilding. The sudden shortage of imported chemico-industrial products and of machinery caused new enterprises in these lines to spring up at home. Lastly, the great accumulation of funds owing to the combined result of the first two factors facilitated the expansion of commercial and industrial activities.

Japanese business men were quick to recognize the opportunities open to them in foreign markets. In a systematic way and along 
broad visioned lines, actively backed by their government, a well organized foreign trade machinery was established with the result that the value of the total exports from that country was trebled in 1918 as compared with 1913 . The value of the exports from Japan to Australia alone increased from $\$ 3,172,830$ in 1913 , to $\$ 14,469,855$ in 1917 .

A new department in Japan's foreign trade policy was the official inspection (conditioning) of certain exports. The purpose of the law under which this inspection is carried on is to establish better grades of quality for Japanese export goods. Thus far the compulsory inspection embraces chiefly textile goods. Celluloid manufactures have recently been added, and also starch. It is sought by this means to maintain the export trade in starch which showed an increase in value of 250 per cent for 1917 over the preceding year.

During the war Japan's exports of cotton cloth have been multiplied fivefold in value, and the government realizes that, if the markets newly gained in China, India, the Dutch Indies, Australia, and the Philippines are to be retained, the quality of Japanese cotton cloths must bear comparison with that of cloths of British and other production. Japanese manufacturers will, therefore, be required by the government to keep their exports up to a fixed high standard. The Department of Agriculture and Commerce announced recently that a scheme was in preparation for the formation of an association of textile manufacturers, which would be charged by the government with strict supervision over goods woven for export. The association will also examine such goods through inspection committees, and bounties will be granted by the government to bear part of the cost of conditioning exports.

In Japan the subsidizing of commerce and trade by the state is practiced on a larger scale than in other countries. During the past four years this policy has been pursued with increased vigor particularly in connection with those industries which are calculated to net large increases in foreign trade.

Under a special law enacted in 1915 the government is authorized to give financial aid to her dyestuffs industry. With this backing, several new plants have been built, and the total amount of capital invested in the more than one hundred factories, exclusive of small ones, is reported to be more than 15,000,000 yen. 
Combined efforts by the government and the textile and chemical industries of Japan to make their country independent of foreign dyestuff manufacturers tie in with an active trade campaign to introduce Japanese dyes in the markets of the Far Eastern countries. For this purpose Japanese manufacturers of dyes and colors have during the past year shown their products at numerous exhibitions at home and abroad.

Japan supplies.about 28 per cent of the total world's consumption of silk and approximately one-third of her total exports prior to the war consisted of raw silk. Comprehensive plans have been made during the war to foster this trade. Under the Raw Silk Industry Act the National Association of Raw Silk Industry of Japan was founded in 1915. The law provides that all local associations shall join the National Association. One of the objects of the new central organization is to develop the export of raw silk and to increase the interests of the raw silk industry. The association has sent a representative to the United States to study the silk conditions in this country and to keep the association informed on all matters pertaining to silk.

The expansion of her merchant marine has been consistently advocated in Japan's foreign trade policy. During the war shipbuilding has been promoted by all possible means, and government subsidies have been freely extended for this purpose. Japanese vessels now run on four great routes to Europe, North America, South America and Australia. There are also lines plying between Japanese ports and Korea, Northern China and nine ports on the Yangtse-Kiang. In return for the subsidies to shipping companies for foreign trade, the Japanese government assumes the right to regulate all inward and outward rates on the products of Japan. It regulates the sailing dates and routes of subsidized boats, and the rates which these boats may charge for export and import cargo, being guided mainly by the desire to build up Japanese foreign trade.

The Japanese banks are active factors in the foreign trade machinery. The Yokahoma Specie Bank, for instance, had its charter modified in order to enlarge its foreign trade department. Other banks also are extending their operations both at home and abroad, and are giving financial help to shipping undertakings. At present they are giving attention to the mineral resources of 
China, including those of the rich Hunan province, and are also reported to be considering the establishment of electrical undertakings in the interior of China with Japanese money, machinery and engineers.

Recently the keenness of the Japanese has been very apparent in the systematic way in which they are extending trade with the Dutch Indies, the South Sea Islands, and Australia and New Zealand. A commercial museum is to be established at Singapore by the Department of Agriculture and Commerce of the Japanese government, with the object of extending Japanese trade through that centre. Not only will merchandise be exhibited, but investigations relating to trade and commerce will be undertaken, and the museum is intended to become a central base of Japan's commercial operations in that part of the world. The establishment of similar institutions is contemplated in due course at other places, including Harbin.

\section{The Marshalling of Trade Forces}

In the foregoing some of the plans have been mentioned which may be considered typical of the world-wide preparations for post-war competition in international trade. An analysis of the whole situation makes it appear that, in the future, competition in the world's markets will be carried on along different lines than in the past. Improved methods of trade expansion and new policies of trade strategy have been introduced. A much greater degree of solidarity of commercial interests has been brought about through the formation of trade associations and combinations of manufacturers and exporters. Through various forms of state participation in industry, especially by granting subsidies, new domestic industries have been firmly established. By means of bank amalgamations and through interlocking directorates huge agglomerations of capital have been effected. International promoting companies have been formed for acquiring and developing mining, transportation and other concessions in foreign countries.

Purchasers and consumers have organized, likewise, largely as a measure of self-protection against monopolistic exploitation. In European countries coöperative purchasing societies have grown rapidly. The French government has promoted the formation of so-called "consortiums," viz., syndicates for purchasing 
and apportioning supplies. In Italy the purchase and sale of several commodities, among them coal, was made a state monopoly under royal decree.

Future competition among the leading commercial nations of the world seems certain to be keener and more intense than ever before.

A survey of the world's trade situation would be incomplete without mentioning a movement to which the war has given a strong impetus and which underlies many of the plans for trade expansion now advocated in foreign countries. This movement aims at establishing economic autonomy. It is most pronounced in Great Britain, France and Germany.

One of the economic lessons taught by the war is the danger of a country's sources of indispensable supplies falling under foreign control. The vital importance to the economic life of a nation both in peace and war, of having certain essential industries firmly established at home, is now generally recognized. Other similar factors helped to quicken this growing movement towards economic nationalism. On an international scale it found expression in the plans to establish a Middle European customs union. It was openly espoused at the economic conferences of the Scandinavian countries, and also at the economic conferences of the Allies at Paris and Rome. The Inter-Empire movement in Great Britain constitutes another phase of this movement. "British goods for British people" has been widely advocated at trade fairs and exhibitions held throughout the British Empire during the past two years. In other countries a similar movement towards national self-sufficiency is noticeable. In line with this policy are the plans. for establishing new tariffs, various kinds of exclusion acts and similar measures of economic offense or defense, as the case may be. The debates in the parliaments of the leading commercial nations of the world on the subject of commercial policy after the war plainly show that there is a widely prevailing apprehension that a policy of "after the soldier, the merchant" would develop after the war. On all sides the fear of economic invasion and commercial penetration is voiced, and means to avoid eventualities of that kind are being urged by party leaders.

In view of this situation the demands of the hour seem to point out the need of constructive action on an international basis for 
the future protection of commerce and trade. A new international code of regulations for the protection of industrial property against unfair methods of competition, dumping, infringements of patents and trademarks, etc., and potent means for ${ }_{\mathscr{A}}$ enforcing agreements of that kind through an international tribunal of commerce and trade, may prove to be one of the most important instruments for preventing friction and promoting good will in the commercial theatre of the world. 